Nr 2(59), 2019, s. 279-297

\author{
Przemysław PAZIK \\ Uniwersytet Warszawski \\ pazik.przemyslaw@gmail.com
}

\title{
KONCEPCJE FEDERACYJNE \\ PODZIEMNEJ UNII (1940-1945): \\ W POSZUKIWANIU POLSKIEGO \\ WZORCA INTEGRACJI EUROPEJSKIEJ ${ }^{1}$
}

ABSTRACT The Federal Ideas of the Clandestine Union (1940-1945): In Search of a Polish Paradigm of European Integration

The article aims at identifying and analysing the particularities of the federalist ideas of a Polish clandestine Catholic organisation the Union. In 1943 the group merged with the Christian-democratic Labour Party (SP), becoming its ideological centre. Throughout the Second World War the Union produced a series of programmatic documents and clandestine press where it discussed the shape of future Europe, which was to become a pan-federation of regional federations cemented by the common values and principles enshrined in Christianity, which were the foundations of Western civilization. In elaborating future plans for Europe, the Union drew explicitly from the memory of the Polish-Lithuanian Commonwealth setting it as an example for modern Poland and other European States. Historical Poland was perceived not just as a state but as a "normative power", this was possible because the Union rejected the modern, 'Westphalian' concept of state. Instead it advocated creation of a pluralistic federation of nations bound together by common values, where national egoisms were mitigated by common Christian values.

Key words: Jerzy Braun, Kazimierz Studentowicz, Central-European federation, intermarium

Słowa kluczowe: Jerzy Braun, Kazimierz Studentowicz, federacja Europy Środkowej, międzymorze 
W

1985 roku Walter Lipgens, redaktor monumentalnej edycji źródeł do historii integracji europejskiej, zauważył: Jest wiele dowodów na to, że w wielonarodowym regionie środkowo-wschodniej i potudniowo-wschodniej Europy [...] świadoma politycznie czesść populacji, a zwtaszcza liderzy opozycji wobec nazizmu uważali federalizm za jedyne możliwe wyjście dla Europy ${ }^{2}$. W przypadku Polski (Lipgens skupiał się na koncepcjach rządu podziemnego, a nie poszczególnych stronnictw) realizacja idei federacyjnych miałaby koncentrować się na utworzeniu bloku państw regionu, który jako całość przyjaźnie ustosunkowywałby się do Zachodu.

Na polskie koncepcje federacyjne XX wieku, w tym z okresu II wojny światowej”, patrzy się dziś przede wszystkim przez pryzmat współczesnej i historycznej geopolityki ${ }^{4}$. Definiowanie regionu jako obszaru „między Rosją a Niemcami”" sprzyja koncentrowaniu się na problematyce bezpieczeństwa i współpracy politycznej. Nie odrzucając możliwości badań w tych kierunkach, warto zwrócić uwagę, że możliwe jest odmienne spojrzenie na kwestię polskiej myśli federacyjnej, właściwe historii kulturowej i historii idei. Jak zauważył Sławomir Łukasiewicz, opis instytucji i dziatań politycznych oraz zwiazanej z nimi myśli politycznej nie bytby petny, gdyby ich dziatania oprzé́ na analizie pism i dokumentów stricte politycznych, pomijając wizje i koncepcje powstające w obszarze szeroko rozumianej myśli politycznej $j^{6}$.

Podążając tym tropem, można stwierdzić, że myśl federacyjna może być opisywana jako element historii kultury. Analiza taka jest wtedy nakierowana na głębsze zrozumienie koncepcji politycznych, a nie na ich aktualizację czy ocenę pod względem szans realizacjī. Poniższy tekst koncentruje się na koncepcjach federacyjnych katolickiej orga-

2 W. Lipgens, East European Plans for the Future of Europe. The Example of Poland, [w:] Documents on History of the European Integration, vol. 1: Continental Plans for European Union, 1939-1945, red. W. Lipgens, Berlin-New York 1986, s. 610 (jeśli nie podano inaczej, wszystkie tłumaczenia pochodzą od autora).

3 Zob. P. Matusak, Idea federacji Europy Środkowo-Wschodniej w planach polskiego podziemia, [w:] Państwa narodowe Europy Środkowo-Wschodniej w XX wieku, red. W. Balcerak, Łowicz-Warszawa 2000, s. 207-222.

4 A. Marszałek, Polskie projekty federacji Europy Środkowo-Wschodniej w latach 1890-1950, Łódź 2008; K. Grygajtis, Polskie idee federacyjne $i$ ich realizacja $w$ XIX i XX w., Częstochowa 2001, zwłaszcza s. 457 i nn.; W. Błasiak, Pomiędzy centrum a peryferiami na progu XXI wieku. Geopolityka i ekonomika Polski i Europy Środkowo-Wschodniej w warunkach integracji europejskiej i światowej depresji gospodarczej, Katowice 2013; M.J. Chodakiewicz, Intermarium. The Land between the Black and Baltic Seas, New Brunswick-London 2012.

5 Tak Janusz Korek zdefiniował horyzont analiz paryskiej „Kultury”, zob. tenże, Ponętna utopia czy zimny realizm. Federacja Europy Środkowo-Wschodniej w myśli politycznejparyskiej „Kultury”, [w:] O nowy ksztatt Europy. XX-wieczne koncepcje federalistyczne w Europie Srodkowo-Wschodniej i ich implikacje dla dyskusji o przysztości Europy, red. J. Kłoczowski, S. Łukasiewicz, Lublin 2003, s. 189-212, cyt. fragment na s. 208.

6 S. Łukasiewicz, Trzecia Europa. Polska myśl federalistyczna w Stanach Zjednoczonych 1940-1971, Warszawa-Lublin 2010, s. 300.

7 Takie podejście do kwestii „międzymorza” zaprezentowat: L. Żyliński, Mitteleuropa (Europa Środkowa) i Międzymorze. Mityczna kraina i historyczny koszmar w okowach wielkiej polityki, [w:] Polsko-niemieckie miejsca pamięci, t. 3: Paralele, red. R. Traba, H.H. Hahn, Warszawa 2012, s. 93-106. 
nizacji Unia z okresu II wojny światowej, które stanowią interesujący epizod w dziejach polskiej myśli politycznej. Myśl polityczna Unii skrystalizowała się, gdy polskie plany i marzenia o powojennej federacji były rozpatrywane jako realne projekty polityczne, jednakże federacja europejska, za którą opowiada się Unia, była projektem nie tyle regionalnym, ile ogólnoeuropejskim. Polska miała odnaleźć swoje miejsce w Europie nie przez jej swoistą „europeizację”, ale przez kulturową „polonizację” reszty kontynentu.

Celem tekstu jest przede wszystkim przedstawienie unionistycznej logiki integracji europejskiej jako elementu pewnej szerszej wizji porządku międzynarodowego. Jak zauważył Rafał Łętocha, uniwersalizm Unii odróżniał stanowisko tej grupy od projektów federacyjnych innych obozów politycznych ${ }^{8}$. Wydaje się, że idea federacyjna czy międzymorska łączyła się w myśleniu unionistów z niektórymi wątkami chrześcijańsko-demokratycznego myślenia o jedności europejskiej’. Ponadto pamięć o Rzeczpospolitej Obojga Narodów oraz wiara w dziejową misję Polski nadały refleksji politycznej unionistów oryginalne cechy. Korzystając ze sformułowania Marka Cichockiego, można powiedzieć, że podziemna Unia pragnęła oddać Europie jej „utracony skarb” ${ }^{10}$.

Połączenie tradycji historycznej i katolickiej nauki społecznej zaowocowało oryginalną teorią integracji, którą dostrzegały też osoby niezwiązane z tą organizacją: $Z d a-$ waliśmy sobie sprawe, że wojna przyniesie donioste zmiany spoteczno-polityczne w naszym kraju, że opracowanie programu ustrojowo-gospodarczego na okres powojenny jest nakazem chwili - wspominał Andrzej Leśniewski, w czasie wojny najpierw student prawa w ramach podziemnego nauczania na Uniwersytecie Warszawskim, a od 1943 roku członek „Mocy”, czyli resortu spraw zagranicznych w ramach Delegatury Rządu na Kraj. Mając wtasne koncepcje [...], próbowaliśmy jednocześnie poznać programy i plany innych [...]. Na pierwszy ogień poszto Stronnictwo Narodowe. Program Stronnictwa Narodowego (SN) nie zdobył uznania grupy młodych prawników: Uderzyt nas zupetny brak realizmu [...]. Polska od Battyku do Morza Czarnego! Jakkolwiek i my zdawaliśmy sobie sprawe z konieczności utworzenia w Europie Środkowej silnego bloku państw, to jednak zatożenie międzymorza budzito w nas wesotość. Zdawaliśmy sobie sprawe z zupetnego braku elementarnych przestanek politycznych, demograficznych i gospodarczych. Kontynuując rozmowy z prawicą, grupa Leśniewskiego spotkała się również z przedstawicielami Konfederacji Narodu $(\mathrm{KN})$, tam jednak również nie doszło do porozumienia.

Zob. np. R. Łętocha, Unia cztowieka z cztowiekiem, narodu z narodem, cztowieka z Bogiem. Wizja tadu międzynarodowego w publicystyce Jerzego Brauna i organizacji Unia, [w:] Kultura chrześcijańska w zjednoczonej Europie, red. T. Sikorski, A. Dymer, Szczecin 2007, s. 185-196; o programie Unii jako utopijnym wspomina K. Przybysz, Wizje Europy w polskiej myśli politycznej 1939-1945, „Rocznik Nauk Politycznych" 1999, nr 1, s. 127.

9 Por. R. Łętocha, Unia cztowieka..., s. 195-196. Łętocha sprowadza UE do projektu demoliberalnego, nie dostrzegając wielu nurtów w myśli o zjednoczonej Europie u początków budowania wspólnoty politycznej i gospodarczej, w tym nurtu chrześcijańskiego. Zob. W. Kaiser, Christian Democracy and the Origins of European Union, Cambridge 2007.

10 Zob. M. Cichocki, Rzeczpospolita - utracony skarb Europy, [w:] Wtadza w polskiej tradycji politycznej. Idee i praktyka, red. J. Kłoczowski, Kraków 2010, s. 21-44. 
Inaczej Leśniewski wspomina rozmowy z - jak sam to określił - „centrum” podziemnej sceny politycznej, czyli właśnie z Unią. Spotkania z Jerzym Braunem, Kazimierzem Studentowiczem i Janem Hoppem ${ }^{11}$ odbywały się w dobrej atmosferze, którą psuły tylko oskarżenia wysuwane przez Studentowicza o „tendencje masońskie” wobec każdego, kto wyraził wątpliwości odnośnie do jego koncepcji. Obawy grupy Leśniewskiego budziło ścisłe powiązanie planów politycznych z religią katolicką, a przecież naród polski byt niemal w catości katolicki, niezależnie od poglądów politycznych ${ }^{12}$.

Powyższy passus dobrze ukazuje, że element religijny, obecny przecież także w koncepcjach SN czy KN, głęboko wpłynął na koncepcje polityczne Unii. Poniżej postaram się wykazać, że to właśnie inspiracja katolicka odpowiadała za istotne przesunięcie akcentów w myśli politycznej unionistów, prowadząc do - jeżeli chodzi o kwestię integracji regionu - modyfikacji koncepcji imperialnych na rzecz projektu uniwersalnego. W ten sposób „geopolityczna” logika integracji znalazła swoje uzupełnienie, a w niektórych momentach została przekroczona dzięki logice religijnej.

Oczywiście powojenny układ sił sprawił, że koncepcja ta nie mogła znaleźć swojej realizacji i podzieliła los wielu innych programów powojennej odbudowy Polski i Europy. Jednakże wydaje się, że opisując przyszłą integrację, autorzy dokumentów programowych i ideologicznych Unii zwrócili uwagę na fakt powiązania integracji politycznej z promocją i realizacją określonych wartości. Zatem, bez używania tego terminu, postrzegali oni Polskę, którą postawili w centrum swojego projektu politycznego, jako potencjalną "potęgę normatywną" w stosunku do Europy: integracja miała być swoistą kulturową polonizacją i re-chrystianizacją Starego Kontynentu.

Stawiając sobie za cel pogłębienie rozumienia koncepcji federacyjnych Unii, w niniejszej pracy analizie poddano dokumenty programowe Unii zebrane w archiwum Instytutu Pamięci Narodowej (depozyty Kazimierza Studentowicza i Jerzego Brauna) oraz Archiwum Akt Nowych, a także wybrane pisma Kazimierza Studentowicza i Jerzego Brauna. Tekst został podzielony na trzy części. Pierwsza przedstawia krótką historię Unii i omawia jej program polityczny. Kolejna odnosi się do problematyki federalizacji Europy Środkowo-Wschodniej. Trzecia część poświęcona jest porównaniu programu i koncepcji integracji unionistów z dwiema konceptualizacjami integracji europejskiej: „potęgi normatywnej” oraz „Europy jako imperium”13. Całość zamykają podsumowania.

Zob. R. Łętocha, „Oportet vos nasci denuo”. Myśl spoteczno-polityczna Jerzego Brauna, Kraków 2006; J. Hoppe, Wspomnienia, przyczynki, refleksje, Londyn 1972; J. Braun, K. Popiel, K. Sieniewicz, Cztowiek ze spizu, Londyn 1982; T. Przeciszewski, Kazimierz Studentowicz - wybitny przywódca, więzień polityczny i teoretyk ruchu chrześcijańsko-spotecznego w Polsce (1903-1992), „Roczniki Nauk Społecznych KUL” 1994/1995, vol. 23, nr 1, s. 209-229; T. Sikorski, Wstęp, [w:] Polski Savonarola. Pisma polityczne Kazimierza Studentowicza z lat wojny i okupacji, red. T. Sikorski, Toruń 2013, s. 15-60.

12 Andrzej Leśniewski, [w:] Przed wrześniem i po wrześniu. Ze wspomnień mtodych dyplomatów II Rzeczypospolitej, red. Z. Czeczot-Gawrak, Warszawa 1998, s. 179-189.

13 I. Manners, Normative Power Europe. A Contradiction in Terms?, „Journal of Common Market Studies" 2002, vol. 40, nr 2, s. 235-258; J. Zielonka, Europa jako imperium. Nowe spojrzenie na Unię Europejska, przeł. A. i J. Maziarscy, Warszawa 2007. 


\section{UNIA I JEJ PROGRAM (1940-1945)}

Unia powstała około 1940 roku - nieznana jest dokładna data - jako federacja mniejszych organizacji podziemnych, budowanych na bazie różnych środowisk: wojskowej organizacji Warszawianka, grupy Nowej Polski wraz ze związanym z nią Teatrem Rapsodycznym, organizacji Grunwald, a także części działaczy Stowarzyszenia Katolickiej Młodzieży Akademickiej Odrodzenie ${ }^{14}$. Organizacje te powstawały naprędce w następstwie klęski wrześniowej, nie podjęły zatem żadnej skoordynowanej refleksji ideologicznej: ta nastąpiła po ich konsolidacji ${ }^{15}$, szczególnie między 1941 a 1943 rokiem, kiedy Unia prowadziła intensywną akcję szkoleniową oraz pracę ideologiczną ${ }^{16}$. W 1943 roku doszło do połączenia Unii - organizacji ideologicznej ze Stronnictwem Pracy (SP). Konstanty Turowski, oceniając skutki tej fuzji, słusznie wskazał na trójczłonowy charakter ruchu chadeckiego, widząc w SP organizację polityczną, w Unii organizację wychowawczą, a w związkach zawodowych (Zjednoczenie Zawodowe Polskie) zalążek organizacji społecznych ${ }^{17}$. Osoby związane z Unią po 1945 roku aktywnie popularyzowały wypracowane w czasie wojny koncepcje na łamach tygodnika SP „Odnowa” oraz „Tygodnika Warszawskiego", jednak po 1945 roku, z powodu zaistniałej sytuacji międzynarodowej i wewnętrznej, zarzucono rozwijanie koncepcji polskiej polityki federalistycznej ${ }^{18}$.

W ramach prac programowych wypracowano rozwiniętą wizję Polski. Warto przyjrzeć się jej dokładnie, ponieważ idea integracji międzynarodowej wydaje sięściśle związana z ideą państwa - im bardziej samodzielne i samowystarczalne jest państwo, tym mniej potrzebna jest współpraca międzynarodowa. W dokumentach programowych opisywano podstawowe zasady ustrojowe, planowane reformy społeczne i gospodarcze, a także ustalano kierunki polityki międzynarodowej, którą odbudowane państwo polskie miało prowadzić. Ustrojem Polski miała być odnowiona demokracja, gdzie decyzje zapadałyby na podstawie prawa „prawdy”, a nie prawa „liczby” ${ }^{19}$. Prowadziło to do ściślejszego niż w przypadku liberalnej demokracji zdefiniowania praw obywateli oraz ściślej łączyło obywatela z państwem.

Ten obraz zasad doktryny Unii nie znajduje w pełni wyrazu w zachowanym projekcie ustawy zasadniczej ${ }^{20}$ - nie sposób jednak stwierdzić, czy zachowany tekst liczą-

14 M. Hańderek, Geneza i początek dziatalności konspiracyjnej Unii, [w:] Polska pod okupacja 19391945, t. 1, red. M. Gałęzowski, Warszawa 2015, s. 122-148; J. Braun, Zarys historii i doktryny Unii 1940-1945, „Chrześcijanin w Świecie” 1985, nr 4, s. 27-37.

15 J. Hoppe, Wspomnienia, przyczynki..., s. 276.

16 K. Turowski, Historia ruchu chrześcijańsko-demokratycznego w Polsce, t. 2, Warszawa 1989, s. 441 i nn; J. Braun, Przyczynek do historii Unii, 14 II 1946, IPN BU 1607/83, k. 65-71; T. Sikorski, Wstęp..., s. 38-60.

17 K. Turowski, Historia ruchu chrześcijańsko-demokratycznego..., s. 448; por. J. Braun, Zarys historii i doktryny..., s. 28-31.

18 W. Bujak, Historia Stronnictwa Pracy 1937-1946-1950, Warszawa 1988, s. 189-192; T. Sikorski, M. Kulesza, Wstęp, [w:] Nieztomni w epoce fatszywych proroków. Środowisko „Tygodnika Warszawskiego" (1945-1948), red. T. Sikorski, M. Kulesza, Warszawa 2013, s. 99-103.

19 Unionizm. Podstawowe zasady doktryny, AAN, „Unia”, sygn. 344/1, k. 4, 5 a.

20 Projekt ustawy zasadniczej, AAN, „Unia”, sygn. 344/2. 
cy 108 artykułów, zajmujących się przede wszystkim kwestiami instytucjonalnymi (art. 27-108), był tekstem bliskim wersji ostatecznej, czy jedynie jedną z wersji roboczych. Wskazuje on, że pełnią praw politycznych cieszyliby się tylko obywatele narodowości polskiej. Niemniej art. 1 projektu głosi, że państwo polskie jest organizacją polityczną narodu polskiego, a zatem (art. 2) nie uznaje się równości wszystkich mieszkańców, przyznając prawa polityczne tylko Polakom (obywatelom). Z katalogiem praw zawartych w art. 4, 8 i 25 (odpowiednio prawa polityczne, gospodarcze i społeczne) zestawiony jest jednocześnie katalog obowiązków obywatela (art. 23), gdzie obok pracy na rzecz narodu wymaga się od obywatela czynnego udziatu w życiu politycznym, zawodowym $i$ kulturalnym $w$ ramach organizacji przez państwo uznanych oraz finansowe poparcie tychże w zależności od swej sytuacji majątkowej.

W projekcie konstytucji można dostrzec elementy chrześcijańsko-demokratyczne, jak np. rozszerzony katalog praw i potrzeba czynnego udziału w życiu politycznym, z drugiej strony nacisk położony na jedność narodu oraz fakt, że życie społeczne ma być regulowane przez państwo, przywodzi na myśl cechy właściwe katolickiemu autorytaryzmowi w duchu Salazara, Franco czy Dollfussa ${ }^{21}$.

Penetracja idei chrześcijańsko-demokratycznych jest bardziej widoczna w ostatnich dokumentach Unii z 1945 roku. Daje się wtedy zauważyć porzucenie idei „organizacji politycznej narodu" na rzecz programu katolicko-społecznego stawiającego w centrum osobę ludzką (humanizm chrześcijański) i widzącego w państwie mechanizm rozwiązania napięcia między jednostką a społecznością. „Uwagi do programu unionistycznego”, o których tu mowa, są bezpośrednio inspirowane kodeksem z Malines ${ }^{22}$, a więc dokumentem stanowiącym ważny punkt odniesienia dla europejskiej chrześcijańskiej demo$\mathrm{kracji}^{23}$. Powyższemu przesunięciu na poziomie idei towarzyszyła modyfikacja na poziomie projektowania ustroju. Braun dostrzegał, że władzę państwa ograniczają niezbywalne prawa osoby oraz prawa samoorganizacji społeczeństwa. Ponadto, w przestrzeni międzynarodowej zdolność państwa do działania ograniczona jest słusznymi prawami innych państw. Z drugiej strony podtrzymano wątek nacjonalistyczny, gdzie mówi się o niemożliwości istnienia wieloetnicznego państwa bez narażenia na szwank jego spójności ${ }^{24}$. Zatem wiara w państwo jako centralny element życia społecznego w myśli unionistów zostaje zachwiana w tym sensie, że podkreślony zostaje służebny charakter państwa wobec

21 Zob. S. Lee, European Dictatorships 1918-1945, Oxford-New York 2016, s. 305-308; P. Skibiński, Państwo generata Franco. Ustrój Hiszpanii w latach 1936-1967, Kraków 2004, s. 24-47, 461-463; H. Wohnout, Middle-class Governmental Party and Secular Arm of the Catholic Church. The Christian Socials in Austria, [w:] Political Catholicism in Europe 1918-1945, red. W. Kaiser, H. Wohnout, London-New York 2004, s. 172-189, zwł. s. 181-182.

22 Kodeks z Malines był owocem pracy Międzynarodowego Związku Badań Społecznych powołanego w 1920 r. w Mechelen (Malines) w Belgii przez kard. Merciera jako kontynuatora Związku Fryburskiego z 1885 r. Oba te ciała za cel stawiały sobie pogłębienie badań społecznych w świetle moralności katolickiej oraz publikowanie wytycznych dla katolickich działaczy społecznych. Zbiorem takich dyrektyw były właśnie kolejne redakcje Kodeksu z Malines, zob. J. Majka, Katolicka nauka spoteczna. Studium historyczno-doktrynalne, Rzym-Lublin 1987, s. 174-175.

23 J. Braun, Uwagi do doktryny unionistycznej, 1946, IPN BU 1607/85, k. 16.

24 Tenże, Ustrój polityczny Polski, 1946, IPN BU 1607/149. 
jednostki: Stawianie państwa czy narodu ponad wszystko [...] jest jednym z największych btędów, jakie można popetnić, pisał w 1945 roku Kazimierz Studentowicz ${ }^{25}$.

Ponadto dostrzega się konieczność istnienia odmiennych od państwa instytucji zapewniających bezpieczeństwo i pokój - stąd potrzeba federacji. Jest to szczególnie widoczne w programie SP z 1944 roku, gdzie odnośnie do porządku międzynarodowego wysuwa się trzy postulaty: po pierwsze - konieczność udziału Polski w budowie nowego porządku, po drugie - uznanie wiążącego charakteru prawa międzynarodowego, które winno być zreformowane w duchu chrześcijańskim, po trzecie wreszcie - SP podnosiło konieczność ochrony słabszych narodów poprzez system federacji kumulujących potencjały mniejszych państw ${ }^{26}$.

Podsumowując, można stwierdzić, że program unionistyczny był wizją organizacji życia państwowego odnoszącą się nie tylko do Polski, ale i do innych krajów Europy. Wychodząc z idei prymatu kultury nad innymi dziedzinami życia, Jerzy Braun wskazywał, że nowa organizacja społeczna powinna być dostosowana do duchowych aspiracji jednostki. Odrodzony porządek hierarchiczny kultury i ekonomii znajduje [...] swój wyraz moralny w konstrukcji polityczno-prawnej. [...] Tylko postęp [...] do rządu idei stworzyć może warunki dla porozumienia się narodów i trwatej organizacji pokoju światowego. Powstanie bowiem wspólny język duchowy, oparty na ideale cywilizacyjnym Europy ${ }^{27}$.

Widać więc, że podczas wojny Unia znajdowała się pomiędzy myśleniem charakterystycznym dla programu obozu narodowego (państwo jako organizacja polityczna narodu) i autorytaryzmu katolickiego (państwo jako uporządkowane życie społeczne organizowane w jego ramach) a myśleniem chrześcijańsko-społecznym (państwo jako narzędzie osób dla ich samorealizacji oraz pokojowego życia w ramach organizmu politycznego). Pod koniec wojny widać rosnącą rolę inspiracji chrześcijańsko-demokratycznej, choć część tez z pierwszej fazy zostaje podtrzymana. Inspiracja chrześcijańsko-społeczna łączyła się w ideologii Unii z wizją historiozoficzną Jerzego Brauna, głoszącego nadejście nowej epoki, w której pokój światowy będzie gwarantowany dzięki wspólnocie cywilizacyjnej wyrażającej się w przyjęciu określonego typu rozwiązań ustrojowych.

\section{MIĘDZY FEDERACJĄ ŚRODKOWOEUROPEJSKĄ A PROJEKTEM UNIWERSALNYM}

Przechodząc do omówienia równoległych wobec prac ustrojowych rozważań nad kształtem porządku międzynarodowego, trzeba zauważyć, że idea federacyjna była obecna w myśli Unii już od samego początku rozwijania refleksji programowej. W tekście z 16 listopada 1940 roku Studentowicz cieszył się z podpisania dokumentów

\footnotetext{
25 [K. Studentowicz], Zatożenia ideowe, IPN BU 1607/70, k. 5.

26 Program Stronnictwa Pracy 15 lipca 1944, Kraków [1945], IPN BU 00231/140/1, s. 28.

27 J. Braun, Przesilenie romantyczne kultury, [w:] tenże, Kultura jutra, czyli Nowe Oświecenie, red. M. Urbanowski, Warszawa 2001, s. 244.
} 
zapowiadających powstanie federacji polsko-czechosłowackiej: $W$ narodzie polskim istnieje federacyjna koncepcja unii. Zdaniem naszym tylko taka koncepcja może przynieść korzyści ze wspótpracy dwóch bratnich narodów ${ }^{28}$.

Okazuje się, że „istniejąca w narodzie polskim koncepcja” nie jest, zdaniem Studentowicza, recepcją innych modelów federacyjnych, ale oryginalnym pomysłem łączenia się państw. Ideolog Unii omawia wpierw pozostałe idee federacyjne: amerykańską i bizantyńską. Pierwsza zakładała połączenie się równych narodów w jeden organizm państwowy, czego historycznymi przykładami miały być Stany Zjednoczone, Szwajcaria czy Stany Generalne Niderlandów. Koncepcja druga miała realizować się przez podbój jednego narodu przez drugi, stąd Studentowicz nazywa model bizantyński „modelem Hitlera”, a spośród innych państw prowadzących tę politykę wymienia też Związek Sowiecki i Japonię. Tak jak w przypadku unii „amerykańskiej” podstawowymi zasadami są równość i dobrowolność, w przypadku unii przez podbój mamy do czynienia z nierównością i brakiem dobrowolności ${ }^{29}$. Katalog Studentowicza został rozszerzony o koncepcję paneuropejską Coudenhove'a-Kalergiego, której istotą miało być zbudowanie jednego narodu europejskiego. Koncepcję tę Unia nie tylko odrzucała, ale i piętnowała jako „masońską”30.

W takim kontekście zaprezentowano koncepcję Unii polskiej, nazwaną też „jagiellońską", a opartą na dwóch założeniach: historycznej misji większych narodów oraz możliwości współpracy narodów mniejszych z większymi bez utraty przez te pierwsze tożsamości. Koncepcja polska miała więc zakładać nierówność i dobrowolność więzów łączących państwa wchodzące w skład takiej unii. Tak też Studentowicz odczytywał historię Rzeczpospolitej Obojga Narodów ${ }^{31}$.

Następnie autor przechodzi do omówienia przyszłej polityki Polski wobec wyzwania zjednoczenia Europy Środkowo-Wschodniej. Odrzuca koncepcję podboju regionu jako niemożliwą materialnie oraz niezgodną z polskim charakterem. Koncepcję unii równych uznaje za niemożliwą, ze względu na niemożność ustalenia wspólnych celów takiej federacji, która osłabiona wewnętrznymi sporami rozpadłaby się albo zamieniła w kolonię sąsiedniego imperium. Unia Polski z Czechosłowacją, a dalej z innymi narodami regionu, miałaby sens tylko, jeżeli narody te zachowałyby i rozwijały własną kulturę, ale zaakceptowały przy tym polskie przywództwo polityczne ${ }^{32}$.

Trzeba podkreślić, że zapowiedź federacji z Czechosłowacją była dla ideologa Unii jedynie pierwszym krokiem do realizacji szeroko zakrojonego programu polityki zagranicznej Polski. Pełny jej kształt można odnaleźć w dokumencie Polityka zagraniczna Polski $i^{33}$. Już na samym początku opracowania postawiony jest cel polityki zagranicz-

28 Unia polsko-czeska, [w:] Polski Savonarola..., s. 422.

29 Tamże, s. 422-423.

30 Światopoglądowe podstawy unionizmu, [1942], AAN „Unia”, 344/1, k. 35a; R. Łętocha, Unia cztowieka..., s. 195 .

$31 \quad$ K. Studentowicz], Unia polsko-czeska..., s. 423.

32 Tami்e, s. 424-425.

33 Jeden z maszynopisów Polityki zagranicznej Polski znajduje się w Archiwum Akt Nowych (zespół „Unia”, sygn. 344/1). Tekst ten został umieszczony w wydaniu pism Studentowicza pod red. T. Sikorskiego, w artykule odnoszę się do tekstu wydanego ze względu na jego dostępność. 
nej Polski: budowa imperium w regionie Trójmorza. Przyczyną jego postawienia jest „eksterminacyjne stanowisko Niemiec jak i Rosji wobec słabszych i zależnych od siebie narodów”. Studentowicz zauważa, że termin „imperium” może razić, dlatego wyjaśnia, że Polski imperializm jest zupełnie innej natury: Tragedia kontynentalnej Europy niepozwalająca jej zjednoczyć się w Stany Zjednoczone starego kontynentu byto, że tylko Polska respektowata ideaty polityczne zdolne doprowadzić do utworzenia tych stanów. Polska, utworzywszy Rzeczpospolita wolnych narodów, zapomniata o sile i dalszej ekspansji, popierajac tym samym wyrok zagtady na siebie $e^{34}$.

Zatem, po pierwsze, imperializm Polski był powodowany jedynie kwestiami bezpieczeństwa (gdy już je zapewniono, ekspansja ustała), po drugie, metoda integracji, którą historycznie przyjęła Rzeczpospolita, mogłaby być zastosowana i w przypadku całego kontynentu, przy budowie Stanów Zjednoczonych Europy. Warunkiem sukcesu tego przedsięwzięcia byłoby jednak „respektowanie ideałów politycznych”, a więc pewnego zespołu norm postępowania politycznego w stosunkach międzynarodowych, diametralnie odmiennych od przyjętych w systemie westfalskim.

Polska spełniała i powinna spełniać istotną historycznie funkcję, która nadaje jej specjalne, większe od jej faktycznej pozycji, znaczenie: Polska jest w tej części świata [...] synonimem pewnej metody życia publicznego i pewnej metody wspótżycia między narodami, metody, która jedna jedyna zdolna jest posuwać naprzód rozwój dziejów ludzkich i której zarzucenie oznacza upadek i powrót do barbarzyństwa ${ }^{35}$. Metoda życia publicznego, o której mowa, oznacza prymat etyki nad dynamiką życia narodowego i międzynarodowego. Dopuszcza ona rywalizację, ale nie eksterminację czy podbój. Powracając do koncepcji jedności europejskiej, Studentowicz podkreśla: gdyby tego rodzaju poglady, tak bardzo wtaściwe duchowi polskiemu, staty się w Europie obowiazujące, to Stany Zjednoczone Europy bytyby juz dawno faktem dokonanym ${ }^{36}$.

Opisana powyżej „metoda unii”, polegająca na włączaniu „sąsiednich krajów w jeden system polityczny", charakteryzować się miała też dwiema istotnymi cechami: respektowaniem praw obywatelskich i samorządności. Jednocześnie autor podkreśla elastyczność takiego rozwiązania - każdy twór, z którym Rzeczpospolita nawiązywała stosunki unijne, negocjował warunki wejścia w taką relację ${ }^{37}$.

Dlatego też unia w koncepcji polskiej to relacja między państwami, która tworzy strefę bezpieczeństwa - wolną od groźby wojny. Zakres tej relacji jest każdorazowo negocjowany - przychodzi tu na myśl koncepcja Europy à la carte - przy poszanowaniu zdefiniowanych zasad podstawowych (praw obywatelskich i samorządności). Potencjalnie unia ta mogłaby rozszerzyć się na całą Europę, tworząc Stany Zjednoczone. W promocji takiego kierunku integracji widzi Studentowicz szansę dla Polski, która mogłaby stać się centrum promieniowania wartości i instytucji unijnych. Do tego jednak konieczna jest realizacja celu geopolitycznego, czyli Unii Środkowo-Europejskiej

\footnotetext{
Polityka zagraniczna Polski, [w:] Polski Savonarola..., s. 434.

Tamże, s. 451.

Tamże, s. 458; Polska - stowiańszczyzna - Europa, [w:] Polski Savonarola..., s. 537-538.

37 Polityka zagraniczna Polski..., s. 458-459.
} 
jako czynnika stabilizującego region oraz punktu wyjścia do nawiązania pokojowych stosunków z innymi regionami Europy ${ }^{38}$.

Idee wypracowane przez Studentowicza były obecne również w myśli Jerzego Brauna - głównego ideologa Unii ${ }^{39}$. W dokumencie Światopogladowe podstawy unionizmu można przeczytać: nowe państwo polskie, chrześcijańskie i unijne przystapić musi do wypetnienia swojej misji na terenie międzynarodowym. Sama jego postawa uniwersalistyczna i mesjanistyczna [...] ale i NAJGEĘBSZA KONIECZNOŚĆ ŻYCIOWA ZMUSZA POLSKE LEŻACA NA SKRZYŻOWANIU POTĘŻNYCH DYNAMIZMÓW HISTORYCZNO-POLITYCZNYCH ZACHODU I WSCHODU DO WALKI O TRWAEY ŁAD MORALNO PRAWNY W CAEEJ EUROPIE ${ }^{40}$. Dalej porównuje się Polskę i jej zasady ustrojowe do Słońca, które rzuca światło na planety. Kulminacją procesu „unionizacji” stosunków europejskich będzie powołanie do życia unii państw chrześcijańskich, opartej na „prawie prawdy”, fundamencie przekraczającym zarówno "gwarancje bez pokrycia" międzywojennych organizacji międzynarodowych (zwłaszcza Ligi Narodów), jak i cyniczny realizm ustrojów dyktatorskich ${ }^{41}$.

Do federacji europejskiej dochodzić się będzie w dwóch etapach. Pierwszy polegać będzie na sformowaniu federacji regionalnych (np. skandynawskiej, łacińskiej czy środkowoeuropejskiej). Prymat wieść tu będzie Polska, która z jednej strony będzie centrum dla projektu środkowoeuropejskiego, a z drugiej - wzorem dla pokrewnych przedsięwzięć. W drugim etapie regiony europejskie połączą się w „związek wyższego rzędu” ufundowany na wspólnym ideale cywilizacyjnym ${ }^{42}$.

Kolejnym istotnym i wspólnym obu myślicielom elementem projektowanej jedności politycznej Europy jest mocarstwowa pozycja w niej Polski. Studentowicz wspominał o ,imperium polskim”. W dokumentach Unii za początek procesu integracji europejskiej uznaje się budowe macierzystego państwa polskiego („matki narodów”) o jak najszerszej bazie terytorialnej. Oparcie o linię Battyku od Szczecina [...] aż po zatoke fiń$s k q^{43}$. Lądowe granice Polski miały obejmować wszystkie dawne tereny Rzeczpospolitej Obojga Narodów, ze specjalnym statusem Ukrainy i Litwy jako narodów (ale nie państw) wchodzących w Unię z narodem polskim. Jednocześnie dopuszczano możliwość powołania państwa ukraińskiego (obejmującego tereny dzisiejszej środkowej i wschodniej Ukrainy). Takie państwo powinno cieszyć się wsparciem Polski, która winna dążyć do wejścia z nim w unię. Na zachodzie postulowano ustanowienie granic na Odrze i Nysie oraz włączenie Prus Wschodnich ${ }^{44}$.

Podobnie jak w zakresie reform ustrojowych, w programie federacyjnym Unii widoczne jest napięcie między „imperializmem” oraz postulatem budowy nowego,

\footnotetext{
Tamże, s. 486.

R. Łętocha, Unia cztowieka..., s. 186.

Majuskuła w tekście oryginalnym.

Światopogladowe podstawy unionizmu..., k. 35a.

Tamże.

43 Tamize.

44 Deklaracja ideowa Unii, AAN, „Unia”, sygn. 344/2, s. 13.
} 
ogólnoświatowego porządku. Opisując imperializm rozumiany jako dążenie do realizacji szczególnej roli Polski w regionie, niezwiązany z bezpośrednim podbojem czy podporządkowaniem istniejących tam państw, Studentowicz powraca do idei, które wyrażał jako członek zespołu redakcyjnego Polskiej idei imperialnej ${ }^{45}$.

Moment zwrotny nadszedł na przełomie 1943 i 1944 roku, kiedy unioniści wyszli z przekonań z okresu romantyzmu politycznego, [...] okresu marzeń o odtworzeniu Polski Jagiellońskiej $^{46}$. Osłabienie oddziaływania idei jagiellońskiej zbiega się z silniejszym oddziaływaniem uniwersalizmu i mesjanizmu. Studentowicz, twierdząc, że ideęnarodowa wytworzona przez Polskę można by nazwać druga z kolei teoria de Civitate Dei, wskazywał na uniwersalny charakter polskiego projektu politycznego. Dlatego propagowanie modelu ustrojowego i wartości, na których został on ufundowany, czyli - jak odnotowuje Studentowicz - budowa imperium, jest warunkiem egzystencji nie tylko dla nas, jak $i$ wszystkich narodów narażonych ustawicznie na ekspansje zaborczości rosyjsko-niemieckiej. Taka ekspansja nie była zdaniem ideologa Unii podbojem, ale zdecydowanym postępem na drodze ku lepszej organizacji ludzkości. Promocja polskości jako ratunku przed ekspansją zaborczych imperiów miała być właśnie „dziejową misją Polski”7.

W realizacji polityki Unii widziano wypełnienie pewnej misji historycznej: Misja Polski [...] jest wypetnienie tej formy politycznej [Europy Środkowo-Wschodniej - P.P.] nowa treścia unionistyczna, w miejsce dotychczasowej treści panslawistycznej i komunistycznej ${ }^{48}$. Unionizm miał być więc nie tyle doktryną polityki zagranicznej, ale pewną propozycją cywilizacyjno-polityczną, skierowaną przede wszystkim do krajów regionu. Uniwersalny charakter „misji” danej grupy, w tym państwa i narodu, jest także podkreślony przez Brauna na poziomie teoretycznym: Misja, czyli stużba celom ogólnym wyznacza racje bytu kazdej jednostki, rodziny, grupy zawodowej [...] czy narodu. Żadna $z$ tych spoteczności nie jest dla siebie celem. Dlatego też Polska, która w ciągu dwudziestolecia międzywojennego prowadziła politykę zagraniczną podług obcych wzorów, po szoku klęski we wrześniu 1939 roku powraca na drogę postannictwa, wzbogacona doświadczeniami i w petni świadoma swojej roli $w$ Europie ${ }^{49}$.

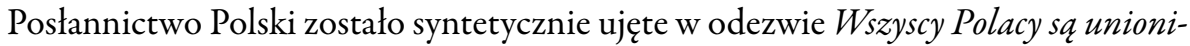
stami, którą pod koniec wojny Unia skierowała do rodaków. W odezwie przedstawiono program unionistyczny jako sumę doświadczeń ludzkości od rewolucji francuskiej, pozwalającą przekroczyć podstawowy dylemat nowoczesnej polityki: alternatywę rządów Boga i suwerenności ludu. Przekroczenie tej opozycji w sferze międzynarodowej jest możliwe dzięki propagowaniu historycznego modelu polskiego, którego cechami, a także podstawowymi zasadami nowej polityki zagranicznej miały być: „solidarność ze słabszymi”, „wolność dla wszystkich”, „niechęć do podboju i wyzysku narodowego czy

45 M. Król, Style politycznego myślenia. Wokót „Buntu Mtodych” i „Polityki”, Wrocław 1981; Polska idea imperialna, red. K. Studentowicz i in., Warszawa 1938.

46 K. Sieniewicz, Jan - pragmatyk, [w:] J. Braun, K. Popiel, K. Sieniewicz, Cztowiek ze spiżu..., s. 90, 111.

47 Polityka zagraniczna Polski..., s. 452.

48 Unionizm. Podstawowe zasady doktryny..., k. 12b.

49 Deklaracja ideowa Unii..., s. 4-5. 
religijnego”, oraz przez „równouprawnienie narodów”. Pokojowy polski wzór kulturowy miał być tym, czego szukać będą narody Europy po wojnie, kiedy caty świat będzie dązyt do moralnego odrodzenia polityki i stworzenia prawdziwej demokracji międzynarodowej. Ten gtód może zaspokoić tylko idea unionistyczna ${ }^{50}$.

Element mesjanistyczny - zapewnienie pokoju Europie, a w dalszych etapach i całemu światu - powoduje więc przekroczenie geopolitycznego programu federacji środkowoeuropejskiej. Obok elementów ściśle związanych z geopolitycznym programem międzymorza czy federacji środkowoeuropejskiej, bezpieczeństwem małych i średnich państw położonych między Rosją a Niemcami, unioniści wysuwają szereg postulatów konstytucyjnych wobec przyszłej formacji politycznej. Chcą oni, by wartości i instytucje, na których oparta będzie przyszła współpraca, były zakorzenione w polskim doświadczeniu historycznym.

W toku dziejów Polska wytworzyła zespół norm i instytucji, które umożliwiały pokojowe współegzystowanie narodów o różnych, ale zbliżonych potencjałach. Taka unia, niezakładająca powstania jednego narodu wynikającego z zespolenia narodów do niej wstępujących, ani nieoparta na podboju i dominacji kulturowej centrum unii, bylaby jedyną drogą do politycznego zjednoczenia kontynentu. Zadanie dziejowe Polski polegałoby w tym przypadku na staniu się motorem takiej integracji i promocji instytucji oraz wartości poprzez wchodzenie w różnego rodzaju relacje z ościennymi narodami: powołanie jednego organizmu państwowego w przypadku krajów Europy Środkowo-Wschodniej; powołanie związku związków regionalnych (np. Europy Łacińskiej czy Skandynawii); wreszcie poprzez zaproponowanie globalnego modelu zarządzania opartego na innych niż Liga Narodów wartościach i metodach działania.

W syntetyczny sposób program ten wyłożono w numerze „Narodu” z lipca 1943 roku: Racja bytu Polski jest petnienie misji dziejowej, polegajacej na wprowadzeniu etyki chrześcijańskiej w życie publiczne i stosunki międzynarodowe. Ściślejszym powotaniem Polski jest zjednoczenie zachodniej i potudniowej Stowiańszczyzny wraz z Ukraina w jedna Rzeczpospolita wolnych i równych narodów, ażeby w oparciu o nia szerzyć dalej wświecie $[. .$.$] cywilizacjęchrześcijańską { }^{51}$.

\section{POLSKA JAKO POTĘGA NORMATYWNA I IMPERIUM}

Przedstawiwszy najistotniejsze cechy projektu federacyjnego unionistów, uniwersalizm „prawa prawdy” oraz centralną rolę Polski i jej misję, w tej części tekstu zaproponuję spojrzenie na myśl federalistyczną unionistów przez pryzmat dwóch pojęć z repertuaru teorii integracji europejskiej: „potęgi normatywnej” i ,imperium”. Do pojęć tych odwołuję się jako do alternatywnych sposobów konceptualizacji jedności europejskiej, mając świadomość, że idee Unii przynależą do porządku myśli politycznej, a nie teorii polityki. Niemniej pojęcia te odnoszą się do podobnego problemu: jedności politycznej

50 Wszyscy Polacy sq unionistami, AAN, „Unia”, sygn. 344/2.

51 Fundamentalne zasady polityki zagranicznej (artykut dyskusyjny), [w:] Polski Savonarola..., s. 548. 
Europy, a ich zestawienie pozwala z jednej strony uchwycić funkcję, jaką inspiracja religijna odegrała w projekcie Unii, a z drugiej strony odsłania istotny aspekt unionistycznej myśli o państwie: odrzucenie paradygmatu westfalskiego na rzecz postrzegania państwa jako istotnego elementu ładu światowego, ograniczonego jednak przez struktury niższego i wyższego rzędu. Innymi słowy, proponowane zestawienie pozwala odpowiedzieć na pytanie o rolę państwa w jednoczącej się Europie oraz postulowany przez Unię mechanizm tej integracji.

Pojęcie „potęgi normatywnej” zaproponował w 2002 roku Ian Manners, poszukując sposobu na uchwycenie specyfiki działania Unii Europejskiej (UE), polegającej na zdolności wpływania na powszechne uznawanie tego, co „normalne”, zarówno w zakresie stosunków międzynarodowych, jak i ustroju państwowego. Koncept ten Manners zaproponował jako uzupełnienie i pogłębienie pojęcia Europy jako potęgi cywilnej ( $c i$ vilian power Europe), którą sformułował François Duchêne: potęga cywilna polegać miała na realizowaniu celów polityki zagranicznej, zwłaszcza tych ekonomicznych, poprzez promowanie współpracy dyplomatycznej i dążenie do tworzenia wiążących państwa ponadnarodowych instytucji ustanowionych w celu osiągnięcia postępu w stosunkach międzynarodowych ${ }^{52}$.

Potrzeba znalezienia nowego pojęcia wynikała z dwóch założeń przyjętych przez brytyjskiego badacza: pojęcie potęgi cywilnej nie potrafiło uchwycić specyficznego charakteru UE, która, nie będąc państwem, nie jest też zwyczajną organizacją międzynarodową. Zatem zarówno cele, jak i metody działania tej „postwestfalskiej wspólnoty politycznej” są inne niż „westfalskiego” państwa i powinny być inaczej analizowane $e^{53}$. Ta konstatacja prowadzi autora do wskazania specyficznej roli norm i kontekstu w powstaniu UE: Kombinacja historycznego kontekstu, hybrydowej spoteczności politycznej (polity) i prawnych fundamentów w po-zimnowojennym świecie przyspieszyta dązenia do umieszczenia uniwersalnych praw $i$ zasad $w$ centrum relacji [UE] z państwami cztonkowskimi i światem ${ }^{54}$. Podstawowymi normami są wyrażone w traktatach dążenie do życia w wolności, demokracji i poszanowanie dla praw człowieka oraz zasad państwa prawa $^{55}$. UE propaguje te wartości, zarówno będąc przykładem dla innych organizacji międzynarodowych, jak i poprzez umieszczanie odwołań do nich w dokumentach prawa międzynarodowego. Czasem promocja wartości następuje przy okazji innych interakcji (np. przy okazji wymiany handlowej) albo w wyniku pogłębionej współpracy między UE a jej partnerem ${ }^{56}$.

W interesującym mnie przypadku myśli politycznej środowiska Unii trudno jest zastosować wprost pojęcie potęgi normatywnej w kształcie zaproponowanym przez Mannersa. Zamiast tego chciałbym podkreślić kilka aspektów pracy teoretycznej brytyjskiego autora, które można, moim zdaniem, odnieść do projektu polskich unionistów.

\footnotetext{
52 I. Manners, Normative Power..., s. 237.

53 Tamże, s. 240-241.

54 Tamże, s. 242.

55 Tamże, s. 243; Traktat o Unii Europejskiej, preambuła.

56 I. Manners, Normative Power..., s. 244-245.
} 
W szczególności warto zwrócić uwagę na hybrydowość UE i jej ufundowanie na wartościach wyrażonych w traktatach założycielskich. Odnośnie do hybrydowego charakteru opisywanej wspólnoty politycznej, można zauważyć, że w refleksji Unii zarówno Polska, jak i Europa mają hybrydowy charakter: Polska ma być federacją obejmującą Polaków, Litwinów, Ukraińców, być może Czechów i Słowaków, każdemu z narodów przyznając należną autonomię. Co więcej, federacyjne państwo polskie ma łączyć się w związki z innymi federacjami, zachowując przy tym pewien rodzaj prymatu wynikającego $\mathrm{z}$ bycia zbiornikiem idei integracji ${ }^{57}$.

W nawiązaniu do normatywnego jądra wspólnoty politycznej, to wartości, które Polska powinna promować, wynikają zarówno z jej chrześcijańskiego charakteru, jak i ze specyficznej i oryginalnej konstytucji. Podstawą życia międzynarodowego ma być „prawo prawdy”, czyli uznanie zarówno doczesnych, jak i nadprzyrodzonych praw człowieka i umiejętność godzenia jednych z drugimi. Konsekwentnie, w życiu międzynarodowym zdaniem unionistów powinna zapanować moralność chrześcijańska - a odrzucone powinno być prawo silniejszego. Ze względu na dominujące tam ideologie z porządku międzynarodowego wykluczono Niemcy i Rosję, przynajmniej dopóki panuje tam nazizm i komunizm ${ }^{58}$.

Co szczególnie interesujące, Polska jest zobowiązana promować wartości chrześcijańskie i swoje wartości konstytucyjne ze względu na swój interes, jak i ze względu na dobro całego Starego Kontynentu. Wyraz tej postawie dał Studentowicz w artykule z jesieni 1943 roku: W przekonaniu Polaków trwaty tad i sprawiedliwość międzynarodowa nie dadza sie osiagnać inaczej, jak przez oparcie przysztej organizacji spoteczno-politycznej Europy na gtębokich zasadach moralności chrześsijańskiej. [...] Idea jedności środkowo-europejskiej nie jest utopia. System unijno-federacyjny stanowi naturalna metode wspótżycia tych narodów. Można by cytować $z$ historii wielokrotne dowody wzajemnego ciążenia ich ku sobie oraz próby stworzenia realnych zwiazków panstwowych, $z$ których największa byta niewątpliwie koncepcja unijna Jagiellonów ${ }^{59}$. Podobnie opisywał to Jerzy Braun: Myśl polska data światu idee unijne i filozofię twórczości, zasady jedności polityki i sumienia, kultury i pracy. [...] Idea ta [...] staje się dzisiaj jedynym ratunkiem i pocieszeniem narodów ${ }^{60}$.

Warto zwrócić uwagę na postulowany „naturalny” charakter unii środkowoeuropejskich - takie ujęcie problemu stanowi de facto odrzucenie westfalskiego pojęcia państwa o jasno zakrojonych granicach i absolutnie suwerennego. Jeżeli naturalnym dla Europy Środkowo-Wschodniej jest tworzenie różnego rodzaju unii, to również granice tych tworów muszą być zmienne i rekonfigurowane (np. przez dołączenie nowego członu czy podział wewnętrzny, gdy jeden z narodów uzyska większą autonomię). Co więcej, trudno mówić o suwerenności takiego tworu w znaczeniu nowożytnym. Co prawda, prowadzić on może własną politykę zagraniczną, ale jest ograniczony przez

Deklaracja ideowa Unii..., s. 15.

58 Tamże, s. 4.

59 Unia środkowo-europejska, [w:] Polski Savonarola..., s. 553-554.

60 J. Braun, Kompromitacja sity, [w:] tenże, Kultura jutra..., s. 124. 
podziały wewnętrzne i przez dążenie do propagowania swojego modelu jako uniwersalnego (likwidacja stosunków międzynarodowych przez unionizację całego świata).

To odrzucenie implicite porządku westfalskiego umożliwia pogodzenie trzech rodzajów potęgi: militarnej i cywilnej (siła bloku państw Europy Środkowo-Wschodniej) oraz normatywnej (promocja wartości chrześcijańsko-jagiellońskich jako wzorca organizacyjno-ideowego dla całej Europy). Skłania też do poszukiwania alternatywnych dla nowożytnego państwa konceptualizacji unii środkowoeuropejskiej. Takim wzorcem wydaje się „neośredniowieczne imperium”, o którym pisał Jan Zielonka ${ }^{61}$.

Teoria Zielonki fundowana jest na przekonaniu o zmierzchu westfalskiego porządku, gdzie władza spoczywałaby w rękach suwerennych państw. Zamiast tego władza w późnonowoczesnym świecie jest rozproszona między wielu różnorodnych aktorów ${ }^{62}$. W ekspansji UE jako imperium pomaga jej atrakcyjność modelu ustrojowego i wysoki poziom życia, co sprawia, że ościenne kraje chcą przyłączyć się do imperium ${ }^{63}$. Integracja ma też ważną rolę stabilizacyjną. O niestabilnych sąsiadach Zielonka pisze wprost: im bardziej sa oni zacofani i niestabilni, tym szybciej trzeba ich do Unii wtaczycíc ${ }^{16} \mathrm{Z}$ drugiej strony, neośredniowieczna UE nie jest scentralizowanym superpaństwem, ale raczej siecią powiązań różnych ciał - regionów, organizacji branżowych czy sieci obywatelskich. Zielonka używa terminu „polifonia” na odróżnienie jego wizji od monofonicznej, scentralizowanej wizji Stanów Zjednoczonych Europy ze stolicą w Brukseli ${ }^{65}$.

Podobieństwa między koncepcjami unionistów a propozycją teoretyczną Zielonki są łatwe do uchwycenia: pluralizm instytucjonalny w ramach porządku państwowego oraz ponad nim, jedność europejska postrzegana jako elastyczna struktura czy uwzględnienie siły normatywnej takiego bytu międzynarodowego pokazują, że stosowana przez Zielonkę metafora UE jako neośredniowiecznej pozwala lepiej zrozumieć pozycję unionistów.

Istotne jest jednak dostrzeżenie poważnych różnic między tymi koncepcjami. Najważniejsza, moim zdaniem, to różnica między siecią a hierarchią - Zielonka widzi neośredniowieczną Europę jako sieć rozproszonej władzy, podczas gdy unioniści podkreślali istniejącą hierarchię i porządek określonych władz, a także ich celów ${ }^{66}$. Nowe średniowiecze wyraża się przede wszystkim przez brak skoncentrowanego ośrodka władzy, a co za tym idzie - brak zasady integracyjnej. W tym sensie jest to projekt na wskroś ponowoczesny. W przeciwieństwie do koncepcji neośredniowiecznej, koncepcja Unii jest ufundowana na jasno zdefiniowanej zasadzie ideowej: chrześcijaństwie. Prowadzi to do klarownego wyróżnienia zakresów władzy, którymi cieszą się poszczególne cia-

${ }^{61}$ J. Zielonka, Europa jako imperium..., passim.

62 Tamże, s. 2-3; G. Lewicki, Sieciowa teoria nowego średniowiecza, „Pressje” 2010, t. 20, s. 77-96; S. Korbin, Back to the Future. Neomedievalism and the Postmodern Digital World Economy, , Journal of International Affairs" 1998, vol. 51, nr 2, s. 361-386.

63 J. Zielonka, Europa jako imperium..., s. 227-228.

64 Tamże, s. 221.

65 J. Zielonka, Koniec Unii Europejskiej?, przeł. E. Gołębiowska, Warszawa 2014, s. 14.

66 R. Łętocha, Unia cztowieka..., s. 196. 
ła społeczne. Innymi słowy, zakwestionowanie nowoczesności prowadzi Zielonkę do afirmacji ponowoczesności, zaś koncepcja Unii kwestionuje nowoczesność, poszukując jej syntezy z tym, co przednowoczesne.

Kontrnowożytny projekt łączył się z zakwestionowaniem nowoczesnego ładu politycznego - podziału na suwerenne państwa. Zamiast tego narody spontanicznie łączyłyby się w związki federacyjne, kierując się bliskością kulturową. Relacje między tymi związkami państw byłyby regulowane prawem międzynarodowym, silnie zakorzenionym w chrześcijańskiej etyce życia społecznego i międzynarodowego.

Polski model integracyjny był nastawiony na zwiększenie potencjału narodowego i promocję idei oraz wartości poprzez wzmocnienie państwa polskiego (definiowanego jednak w sposób prewestfalski) jako moralnego i politycznego lidera integracji - stąd podkreślanie misji Polski. Warto w tym miejscu powrócić do rozróżnienia koncepcji federacyjnych przez Studentowicza - wyróżniono tam między innymi typ „amerykańsko-szwajcarski” oraz typ „polski”, a zasadnicza różnica między nimi polegała na tym, że w drugim przypadku proces integracji był inspirowany i wdrażany przez jedno państwo, wciągające kolejne państwa do federacji, podczas gdy pierwszy przypadek zakładał istnienie momentu konstytuującego federację, która potem może być ewentualnie rozszerzana.

Polscy unioniści poprzez odwołanie się do tradycji Rzeczpospolitej oraz tradycji mesjanistycznej zaproponowali oryginalną wizję przekroczenia podziałów państwowych poprzez unie między narodami. W tym sensie ideolodzy Unii podejmowali próbę aktualizacji ideału Rzeczpospolitej i wprowadzenia go do kanonu europejskiego myślenia o państwie. Tradycja mesjanistyczna kazała im upatrywać w Polsce kraj predestynowany do rozpowszechniania tego modelu współżycia międzynarodowego, co uzasadniać miało jej centralną pozycję w przyszłym ładzie europejskim i światowym.

\section{KONKLUZJE}

W powyższym artykule podjęto próbę spojrzenia na federacyjne koncepcje podziemnej Unii w latach 1941-1945 w świetle jej dokumentów programowych oraz pism autorów odpowiedzialnych za linię organizacji. W tym okresie program Unii ewoluuje: odchodzi się od postulatu budowy państwa wyznaniowego, w kształcie podobnym do katolickich dyktatur międzywojennych, zamiast tego w refleksji programowej Unii zaczynają dominować elementy personalistyczne i demokratyczne. Pojawia się hasło pełnej demokracji i uznanie osoby ludzkiej oraz jej autonomii za podstawę ustroju spowodowało modyfikację, jeżeli chodzi o planowany ustrój.

W zakresie myśli federacyjnej przemiana ta jest widoczna, gdy rozważa się cechy projektowanej federacji środkowoeuropejskiej. Jej bezpośrednim celem było zapewnienie Polsce mocarstwowego statusu i bezpieczeństwa przed agresją niemiecką czy rosyjską. Jednakże odniesienie się do idei mesjanistycznych oraz chrześcijańskiej wizji stosunków międzynarodowych spowodowało rozszerzenie programu unionistycznego. Celem stało się nie tylko zbudowanie regionalnego imperium, ale promocja pewnych 
zasad ustrojowych - innymi słowy, Rzeczpospolita Obojga Narodów stała się nie tylko horyzontem geopolitycznym, ale również typem idealnym nowego rodzaju stosunków między narodami. Idealizowana Rzeczpospolita była zarówno państwem, jak i federacją pokojowo wspólistniejących narodów.

Pogłębiona analiza myśli Unii przy odwołaniu się do pojęć potęgi normatywnej oraz Europy jako imperium pozwala dostrzec, że Polska nie jest w niej traktowana jako państwo w znaczeniu nowożytnym, ale jako pewnego rodzaju nośnik i propagator ładu międzynarodowego. To historyczny polski model państwowy i federacyjny ma być lekarstwem na klęskę nowożytnego ładu opartego na suwerennych państwach.

W świetle powyższego można zauważyć, że ta oryginalna polska myśl stała się nieaktualna w momencie sukcesu ZSRR w wojnie z Hitlerem, a potem dzięki zagwarantowaniu Stalinowi na konferencji w Jałcie panowania nad Europą Środkową i Wschodnią ${ }^{67}$. Gdy Europa zaczynała się jednoczyć na zachodzie, Polska jako państwo nie mogła wziąć udziału w tym procesie ${ }^{68}$. Był to proces integracji według innych planów $i$ idei, niż liczyli na to Braun i Studentowicz: zamiast orientacji jagiellońskiej obowiązywały podejścia funkcjonalistyczne i federalistyczne (w znaczeniu „amerykańsko-szwajcarskim”) do jednoczenia się kontynentu. Politycy SP na emigracji, zaangażowani w działalność międzynarodówki chrześcijańsko-demokratycznej, nie mogli skutecznie odwoływać się do dorobku programowego lat wojny. Potencjał intelektualny każe spojrzeć na Unię jako na wyjątkowy ośrodek wypracowywania koncepcji politycznych i historiozoficznych dla Polski ${ }^{69}$. Ponieważ koncepcje te nie znalazły miejsca w oficjalnym życiu publicznym PRL, warto postawić sobie pytanie, czy idee te zniknęły z polskiego życia kulturalnego, czy może jednak były przekazywane drogą nieformalnych kontaktów i w prywatnych dyskusjach, łącząc tym samym doświadczenie Unii z późniejszymi przejawami żywotności idei jagiellońskich, federacyjnych i mesjanistycznych w Polsce.

\section{BIBLIOGRAFIA}

Błasiak W., Pomiędzy centrum a peryferiami na progu XXI wieku. Geopolityka i ekonomika Polski i Europy Środkowo-Wschodniej w warunkach integracji europejskiej i światowej depresji gospodarczej, Katowice 2013.

Braun J., Kultura jutra, czyli Nowe Oświecenie, red. M. Urbanowski, Warszawa 2001.

Braun J., Przyczynek do historii Unii, 14 II 1946, IPN BU 1607/83.

Braun J., Ustrójpolityczny Polski, 1946, IPN BU 1607/149.

Braun J., Uwagi do doktryny unionistycznej, 1946, IPN BU 1607/85.

67 J. Łaptos, Europa jedna czy dwie? Projekty i koncepcje integracji europejskiej w latach 1944-1950, Kraków 1994, s. 49-52.

68 Aktywnie uczestniczyli w nim polscy emigranci polityczni: zob. np. J. Łukasiewicz, Trzecia Europa...; J. Łaptos, Europa marzycieli. Wizje i projekty integracyjne środkowoeuropejskiej emigracji politycznej 1940-1956, Kraków 2012.

69 Przegląd postaci i grup związanych z Unią: J. Braun, Jan Hoppe - polityk w stużbie idei, [w:] Cztowiek ze spizu..., s. 137-153. 
Braun J., Zarys historii i doktryny Unii 1940-1945, „Chrześcijanin w Świecie” 1985, nr 4.

Braun J., Popiel K., Sieniewicz K., Cztowiek ze spizu, Londyn 1982.

Bujak W., Historia Stronnictwa Pracy 1937-1946-1950, Warszawa 1988.

Chodakiewicz M.J., Intermarium. The Land between the Black and Baltic Seas, New Brunswick-London 2012.

Cichocki M., Rzeczpospolita - utracony skarb Europy, [w:] Wtadza w polskiej tradycji politycznej. Idee i praktyka, red. J. Kłoczowski, Kraków 2010.

Deklaracja ideowa Unii, AAN, „Unia”, sygn. 344/2.

Grygajtis K., Polskie idee federacyjne i ich realizacja w XIX i XX w., Częstochowa 2001.

Hańderek M., Geneza i początek dziatalności konspiracyjnej Unii, [w:] Polska pod okupacja 19391945, t. 1, red. M. Gałęzowski, Warszawa 2015, s. 122-148.

Hoppe J., Wspomnienia, przyczynki, refleksje, Londyn 1972.

Kaiser W., Christian Democracy and the Origins of European Union, Cambridge 2007.

Korbin S., Back to the Future. Neomedievalism and the Postmodern Digital World Economy, „Journal of International Affairs" 1998, vol. 51, nr 2.

Korek J., Ponętna utopia czy zimny realizm. Federacja Europy Środkowo-Wschodniej w myśli politycznej paryskiej „Kultury”, [w:] O nowy ksztatt Europy. XX-wieczne koncepcje federalistyczne w Europie Środkowo-Wschodniej i ich implikacje dla dyskusji o przysztości Europy, red. J. Kłoczowski, S. Łukasiewicz, Lublin 2003.

Król M., Style politycznego myślenia. Wokót „Buntu Mtodych” i „Polityki”, Wrocław 1981.

Lee S., European Dictatorships 1918-1945, Oxford-New York 2016.

Lewicki G., Sieciowa teoria nowego średniowiecza, „Pressje” 2010, t. 20.

Lipgens W., East European Plans for the Future of Europe. The Example of Poland, [w:] Documents on History of the European Integration, vol. 1: Continental Plans for European Union, 1939-1945, red. W. Lipgens, Berlin-New York 1986.

Łaptos J., Europa jedna czy dwie? Projekty i koncepcje integracji europejskiej w latach 1944-1950, Kraków 1994.

Łaptos J., Europa marzycieli. Wizje i projekty integracyjne środkowoeuropejskiej emigracji politycznej 1940-1956, Kraków 2012.

Łętocha R., „Oportet vos nasci denuo”. Myśl spoteczno-polityczna Jerzego Brauna, Kraków 2006.

Łętocha R., Unia cztowieka z cztowiekiem, narodu z narodem, cztowieka z Bogiem. Wizja tadu międzynarodowego w publicystyce Jerzego Brauna i organizacji Unia, [w:] Kultura chrześcijańska w zjednoczonej Europie, red. T. Sikorski, A. Dymer, Szczecin 2007.

Łukasiewicz S., Trzecia Europa. Polska myśl federalistyczna w Stanach Zjednoczonych 19401971, Warszawa-Lublin 2010.

Majka J., Katolicka nauka spoteczna. Studium historyczno-doktrynalne, Rzym-Lublin 1987.

Manners I., Normative Power Europe. A Contradiction in Terms?, "Journal of Common Market Studies" 2002, vol. 40, nr 2, [online] https://doi.org/10.1111/1468-5965.00353.

Marszałek A., Polskie projekty federacji Europy Środkowo-Wschodniej w latach 1890-1950, Łódź 2008.

Matusak P., Idea federacji Europy Środkowo-wschodniej w planach polskiego podziemia, [w:] Państwa narodowe Europy Środkowo-Wschodniej w XX wieku, red. W. Balcerak, Łowicz-Warszawa 2000. 
Nieztomni w epoce fatszywych proroków. Środowisko „Tygodnika Warszawskiego” (1945-1948), red. T. Sikorski, M. Kulesza, Warszawa 2013.

Polska idea imperialna, red. K. Studentowicz i in., Warszawa 1938.

Polski Savonarola. Pisma polityczne Kazimierza Studentowicza $z$ lat wojny i okupacji, red. T. Sikorski, Toruń 2013.

Program Stronnictwa Pracy 15 lipca 1944, Kraków [1945], IPN BU 00231/140/1.

Projekt ustawy zasadniczej, AAN, „Unia”, sygn. 344/2.

Przeciszewski T., Kazimierz Studentowicz - wybitny przywódca, więzień polityczny i teoretyk ruchu chrzéscijańsko-spotecznego w Polsce (1903-1992), „Roczniki Nauk Społecznych KUL” 1994/1995, vol. 23, nr 1, s. 209-229.

Przed wrześniem i po wrześniu. Ze wspomnień mtodych dyplomatów II Rzeczypospolitej, red. Z. Czeczot-Gawrak, Warszawa 1998.

Przybysz K., Wizje Europy w polskiej myśli politycznej 1939-1945, „Rocznik Nauk Politycznych” 1999, nr 1.

Skibiński P., Państwo generata Franco. Ustrój Hiszpanii w latach 1936-1967, Kraków 2004.

[Studentowicz K.], Zatożenia ideowe, IPN BU 1607/70.

Światopogladowe podstawy unionizmu, [1942], AAN „Unia”, 344/1.

Turowski K., Historia ruchu chrześcijańsko-demokratycznego w Polsce, t. 2, Warszawa 1989.

Unionizm. Podstawowe zasady doktryny, AAN, „Unia”, sygn. 344/1.

Wohnout H., Middle-class Governmental Party and Secular Arm of the Catholic Church. The Christian Socials in Austria, [w:] Political Catholicism in Europe 1918-1945, red. W. Kaiser, H. Wohnout, London-New York 2004.

Zielonka J., Europa jako imperium. Nowe spojrzenie na Unię Europejska, przeł. A. i J. Maziarscy, Warszawa 2007.

Zielonka J., Koniec Unii Europejskiej?, przeł. E. Gołębiowska, Warszawa 2014.

Żyliński L., Mitteleuropa (Europa Środkowa) i Międzymorze. Mityczna kraina i historyczny koszmar w okowach wielkiej polityki, [w:] Polsko-niemieckie miejsca pamięci, t. 3: Paralele, red. R. Traba, H.H. Hahn, Warszawa 2012.

Przemysław PAZIK - dr nauk historycznych, w latach 2015-2018 asystent w Katedrze Cywilizacji Europejskiej w Kolegium Europejskim (Natolin). W 2019 roku obronił doktorat na Wydziale Historycznym UW. Naukowo zajmuje się historią myśli politycznej inspirowanej katolicyzmem w XX wieku. 